\title{
Influence of energy paradigm shifts on city boundaries. The productive peripheries of Madrid
}

\author{
Carlota Sáenz de Tejada Granados, Eva J. Rodríguez Romero, Rocío \\ Santo-Tomás Muro \\ Departamento de Arquitectura y Diseño. Universidad CEU San Pablo. Escuela Politécnica \\ Superior. Spain \\ E-mail: carlota.saenztejada@ceu.es, rodrom@ceu.es, \\ rocio.santotomasmuro@beca.ceu.es
}

\begin{abstract}
The promotion or access to certain energy technologies has changed the humanized landscape throughout history; cities have been born around, and because of an energy source, or have been displaced in order for energyrelated infrastructures to take their spot. However, and for any city from its very beginning, energy paradigm shifts have deeply altered their morphology. Not only extraction, but especially transformation and transport of resources materializes in artefacts, often controversial and soon-to-be obsolete. This is especially patent in the ever-changing city boundaries; the fringe of 'proximity', where the collision between the countryside and the urban mesh embodies the relations and contradictions between urban growth, energy demand and landscape protection. In a context of growing cities (both in terms of expansion of its artificial land and in terms of energy demand), we are facing two paths which not always converge: an inevitable low carbon transition and a growing sensitivity towards ordinary landscapes. This article, within the framework of the project 'Proximity landscapes of the city of Madrid. From the 19thC to the present', studies the development of the city of Madrid in relation to its energy access and management, in a series of key stages: mid 19thC (before the bourgeois enlargement plan approved in 1860), early 20thC (when the introduction of electricity powered a deep urban transformation and outlaying urban cores were annexed), mid-late 20thC (when a rural exodus took place and the peripheries of Madrid grew rapidly) and today.
\end{abstract}

Keywords: energy landscape, periphery, urban history, urban form, Madrid.

\section{Introduction}

Historically, urban settlements have changed over time according to the availability of energy. The preindustrial city rarely exceeded half a million inhabitants, lacking the logistics and energy needed to grow significantly (Ivancic, 2010). With the Industrial Revolution came an exponential urban development, boosted by the technology to transport electricity over larger distances in the late nineteenth century. Gas plants proliferated in urban areas, defining the skyline of many cities in the late nineteenth and early twentieth century. With the widespread use of electricity and private cars came a strong urban growth and a fading of the urban-rural barrier.

In a context of low carbon transition and growing sensitivity towards ordinary landscapes (Council of Europe, 2000), the deployment of low-carbon technologies is often finding local social opposition, mainly linked to its visual impact (Van der Hosrt, LozadaEllison, 2010). A dynamical view of landscape 
history can be help face the integration of new paradigms (Palang et al., 2011); as done with previous energy artifacts throughout the cities' successive transformations, we must be ready to incorporate the new into our collective imagery.

The peri-urban landscape, so prone to change, embodies the relations and contradictions between urban growth, energy demand and landscape protection, and is particularly relevant when facing future challenges. Madrid, a highly populated, highly consumptive and scarcely productive electric energy region (Fenercom, 2016), provides an example of a complex expansion of a city core. This work searches to study its evolution since the mid-nineteenth century to the present, and detect the driving forces of landscape change, particularly in its southern boundary.

\section{Methodology}

The development of the city of Madrid in relation to its energy supply and infrastructures is studied my means of a critical evolutionary analysis at different scales and times. It is presented in a chronological order, divided in four periods that relate to relevant phases of the city's transformation: mid-19th century, early 20 th century, mid-late 20 th century and recent times.

From a metropolitan scope, the focus is put on the south urban boundary; an area with a productive role during the industrialization process, embedded today in the denser residential urban fabric of the city center, however bearer of great industrial heritage and character. Zooms at a same scale and frame allows for a comprehensive reading of this transformation.

The overlapping of thematic layers (land use, electricity network, areas of urban regeneration and of environmental protection) is done using historical cartography, orthophotography and GIS databases, among other documentary evidence.

\section{Evolutionary analysis Mid-nineteenth century}

Madrid in the 1850s suffered a series of infrastructural shortcomings that prevented it from experiencing an industrial development as other regions were experiencing at that time. Its poor rural surroundings did not provide enough agricultural raw materials, minerals or fuel, making energy expensive and insufficient. Its geographical location, far from any important port or country border, was another challenge the city would gradually have to overcome.

River Manzanares had always lacked the scale and flow to have determined the foundation of the city of Madrid. The fresh water was provided by underground streams (viajes de agua). However, these fell short to meet the growing needs of a city that was suffering scarcity. Canal de Isabel II captured water from River Lozoya, in the northern mountain range, and transported it $77 \mathrm{~km}$ to Madrid. Though the underground waters would still be used long after the creation of this channel, the city now had the capacity to undertake a strong urban growth (Rodríguez, 2003). And so, it did. The Enlargement Plan designed by Carlos $\mathrm{M}^{\mathrm{a}}$ de Castro in 1857, approved in 1860, doubled the surface of the city in a matter of a few years and spread mainly towards the north and northeast of the urban core; higher lands, which had been difficult to supply with water from the traditional underground streams. The population in 1900 had also doubled since 1850, exceeding the half million inhabitants due to an intense migratory movement from the country to the city (Vicente, 2015).

A succession of walls girded Madrid up to then; since its Islamic origin, first with defensive walls, and later with fences devoted mainly to taxation purposes. The infrastructure associated to the Canal de Isabel II was sited in a highly accessible area, north of the city and outside its fence (demolished in 1869). There had not yet been a design for an urban extension towards the north outskirts of the city, and the failure to foresee this urban growth made the water supply to the northern buildings of the Enlargement Plan far more difficult than expected, since the terrain where blocks were sited was higher than the water deposits and 
channel, and there was not enough pressure by gravity.

Gas had arrived to replace oil as the fuel used in the lighting of the city. In 1847, the first three streets were lit by gas in Madrid (Paseo del Prado, Prado Street and Lobo Street). Its use would later extend to domestic heating and lighting. The Gas Factory became the largest industry in the city by the mid-nineteenth century. Gas storage units, ovens, warehouses, coal storage, laboratories and offices were some of the infrastructures associated to this industry, located in the southern border of the city: a first step in the conformation of a clearly industrial character in this area, later reinforced by the introduction of the railway and electricity systems.

The use of electricity, as in the case of gas, started with public lighting. Though first used in the Royal Palace in 1852, it was not widespread until the last decades of the century. The production of electricity with steam engines, based on coal, was the most extended in urban contexts. Once proved it could be a commercially feasible endeavor, a series of small-scale companies emerged throughout the city, usually generating and distributing electricity for the surrounding neighborhood. The overhead line was the transportation system chosen in European cities. However, in all cases, the distances were quite short. Only from 1889 onwards, with the direct current, could it be possible to consider taking the production of the electricity outside the city centers, taking advantage of the energy produced by water falls (Terán, 2006).

By the end of the nineteenth century, the city was expanding, though the Enlargement Plan would not be considered complete until 1932. Meanwhile, population concentrations were appearing outside the limits of the enlargement project; these would be the origin of districts such as Cuatro Caminos, Tetuán, Carretera de Aragón, Puente de Vallecas and Barrio de Extremadura (Rodríguez, 2003). The spontaneous arise of these clusters of population along the main accesses to Madrid made it necessary to elaborate projects to organize, manage and design the future growth of the periphery of the city. Therefore, by the beginnings of the twentieth century, new urban needs called for interior restructuring and management of the outskirts of the enlargement's boundaries.

\section{Early twentieth century}

In contrast to other European capitals, such as London or Paris, the productive and commercial fabric of Madrid in the 1850s was more artisanal than industrial. However, the development of the gas industry, electricity network and railway system changed this situation.

The original stations in Madrid were Atocha (for long-distance trains coming from the south and east) and Príncipe Pío station (for those coming from the north and west). The tracks entered the city through the river, and the stations would lie next to it due to the difficulty to surmount the steep cornice to the west. Soon Atocha and Príncipe Pío would prove insufficient for the growing activity, and other stations would start to appear along the south district (Delicias, Imperial and Peñuelas).

The railway transformed the weakness of Madrid's geographical location into a strength, making it the central operator of a national network that did not have an alternative means of transportation. Figure 1 shows how the siting of the industrial use would be strongly influenced by the presence of the railway stations and tracks, especially by the bypass built in 1860 to connect them (Pinto, 19952001).

The tall chimneys of the gas plants had become a part of the urban landscape of the early-twentieth-century cities; the one shown in Figure 1 is still in its place today, however the rest of the plant was demolished in 1967. The site now holds a block of housing and a small park where the obsolete chimney stands as a remnant of what was once there.

The waste waters that flowed into River Manzanares, along with the irregular flow and scarcity during the summer, made the channeling of its urban sector an imperative matter, to improve both sanitary conditions and aesthetics. The project to do so was approved in 1912, and works started in 1914. Over 
$7.5 \mathrm{~km}$ were channeled (from Puente de los Franceses to Abroñigal stream), and the works were completed by 1925 .

Another facet of this new age was the public transportation system. Madrid's first subway lineopenedin 1919, connecting Cuatro Caminos with Puerta del Sol, strongly influencing the urban development of the northern part of the city. The Metropolitan Development Company (Compañía Urbanizadora Metropolitana), would buy great extensions of cheap land for engine sheds and electrical energy generation needed for its development. The growth of this network fostered the proliferation of electrical substations to feed it, and fostered urban regeneration plans, especially in the northern enlargement urban mesh, mending certain clashes between the different urban textures of the most consolidated enlargement fabric and the less dense areas to the west, such as Ciudad Universitaria (Olivares, 2016).

The electrical panorama left by the end of the past century (a network of small electricity companies scattered around the city and supplying only within the district) would come to an end in the beginning of the twentieth century. The management and transport of high voltage lines made the transition from thermoelectric to hydroelectric energy (far from the urban center) possible, and was particularly important for Madrid, located far from any coal reserve that fueled the thermal steam plants. This change of paradigm also enabled powerful financial conglomerates to gradually absorb the smaller companies. The most important groups were Unión Eléctrica Madrileña, Cooperativa Electra Madrid and, at a smaller scale, Hidráulica Santillana and Canal de Isabel II.

Figure 2 shows how, by 1945, the electric energy reached the city mainly through the south and southwest boundaries, coming from the hydroelectric plants of the main groups mentioned above. Only a small proportion of the energy that arrived in Madrid did it from the north, by the networks of Hidráulica Santillana and Canal de Isabel II. There were still old grids of direct current, though they were progressively disappearing in favor of the more modern alternating current.

Both the subway and the trams system (the two main public transportations in Madrid at the time) worked in direct current. Three transformation plants were associated to the subway network (Pacífico, Castelló and Olid), and another three to the tram system (Mazarredo, Gobernador and San Bernardo), though a fourth one for the tram (Goya) was in progress. The distribution grids inside the city center were almost entirely underground at the time; only in the periphery, where the urbanization and tracing of roads were subject to change, were there overhead tension lines (Spottorno, 1945).

Migration to the capital was a constant flow. The demographic growth was forcing another urban expansion. First in the closer periphery, but soon after, the old towns of the broader periphery of Madrid, devoted to agricultural or farming activities (in the shadow of an industrializing capital), were subject to the gravitational field of the city of Madrid (Vicente, 2015). Soaring housing prices in the city center had driven the less qualified working class away from the southern area of Madrid (which was now becoming part of the central area of the urban metropolis) to the more affordable periphery, along with some production centers that were moved from the urban core to industrial estates in the farther outskirts.

\section{Mid-late twentieth century}

After the Spanish Civil War (1936-39), in 1948 started a process of annexation of thirteen outlaying cores to the municipality of Madrid. This gradual process would take until 1954, and resulted in the surface of the city of Madrid being eight times larger than what it used to be. As stated above, the peripheral urban cores had already been influenced by the growing city center and, during the second half of the twentieth century, the urban fabric would continue to fill in the voids in a succession of urban developments that respected two elements which, still today, constitute Madrid's major 'green lungs': Casa de Campo and El Pardo Mount.

Towards 1950, three Spanish cities registered the greatest population increases of their 
history, while fourteen other clearly decimated. Madrid, Barcelona and Bilbao doubled and tripled their size, and seemed to overflow with this 'rural exodus'. The countryside would empty (del Molino, 2016), strongly altering the city-countryside balance.

Spain in the 1970s paired its transition to democracy with the 'Oil Crisis' of 1973; an event that strongly impacted the industrialized economies worldwide, due to their high dependency of petroleum. Consumption restrictions and higher energy prices made production costs suddenly unbearable for a considerable number of industries. Madrid experienced a deceleration in the growing trend of the past years, and a paradigm shift took place in terms of urban growth and landscape values. A more social approach to urban planning (reflected in land-use policy at many scales during the next decade) would be less keen to conquer new lands, and would focus on mending the unresolved fragments of the existing city (voids, interior peripheries and clashes left between the boundaries of successive urban growths and obsolete infrastructures).

An example of this is the Pasillo Verde (green corridor) project, approved in 1989. The railway technology has evolved since it was first settled, and such large associated infrastructures were not needed anymore. Alongside, many industries had been shifted to industrial sites farther from the city center, leaving the area of study ready for a re-zoning into residential use. As shown in Figure 3, the plan reorders the voids left after limiting the use of the railway to the transport of passengers in a double track to Atocha station. The metropolitan role of Príncipe Pío station is reinforced, and the stations in between are reduced to mere halts along the way to Atocha. Rosales and Tierno Galván Parks are extended, and Peñuelas Park is created. It is worth highlighting, within this project, the tree-lined promenade that would be built over the underground rail tracks (zoom in Figure 3), with housing and offices at both sides, and endowed with a series of squares and small parks along its linear morphology.

On a larger scale, in the period between 1982 and 2006, the population in the region of Madrid grew 1.3 million, while artificial land increased by $97 \%$ (Gallardo, Martínez-Vega, 2016). Madrid had experienced a rapid economic growth in the last two decades, which led to large territorial transformations and extensive change in land use. Alongside (since the 1980s) came a conceptual change in terms of local identity of the people living in the periphery; the outskirt neighborhoods substituted the rural town as a source of pride and belonging (del Molino, 2016) and a recent, socially charged, awareness of ordinary landscapes shifted the viewpoints towards formerly disregarded areas, such as the east and south of the city (Rodríguez, Sáenz de Tejada, 2016).

\section{Recent times}

The area of study, as shown in Figure 4, is now densely populated with housing blocks, though there is still a strong presence of railway infrastructures (mainly around Atocha station). Industrial sites seem to gravitate around them, while the river is now flanked by an urban linear park. Madrid Río Urban Renewal Plan (2008-2010) entailed tunneling a large section of the M-30 ring-road, thus allowing the design of a park along the riversides.

Urban greening trends have been very present in the urban agenda at a municipal level in recent years. A Strategic Municipal Plan of Madrid was commissioned by the City Council in 2009 to reflect on innovative approaches to urban design and studies, facing the challenges of globalization, climate change and social transformation. Another example of this dynamic is the MAD-RE Plan for Urban Regeneration; a long-term project initiated in 2016 by the Area for Sustainable Urban Development of Madrid City Council. It aims to promote accessibility, conservation and energy efficiency upgrades in dwellings by means of subsidies, and defines strategic areas of intervention to address improvements in the public space. Figure 4 shows some preferential areas of urban regeneration within the area of study, as well as areas of opportunity for new developments to be undertaken in a near future. However, most areas of intervention and opportunity in this Urban Regeneration Plan are farther from the urban core, in the southern half 
of the fringe between the first and second ringroad (M-30 and M-40 respectively). This falls out of the boundaries of our closer-scale case of study, but nevertheless is related to the shift of uses this area undertook during the second half of the twentieth century, driving some of the major production centers to industrial estates in more affordable peripheral locations. Today these areas, due to the city's growth and transportation systems, are within the 'proximity landscapes' of Madrid, embedded in a complex urban-rural fabric.

As mentioned above, the recent growth of artificial land in the region of Madrid has not been directly linked to a population growth; new urban developments have been placed around new roads (M-45, M-50, R-2, R-3, R-4 and R-5), as well as commercial and leisure centers (especially in the south of the metropolis). The expansion of Barajas airport nurtured a nearby urban growth of associated uses (Gallardo, Martínez-Vega, 2016).

Returning to the subject of electricity, we find ourselves today with a strongly consumptive (and scarcely productive) 'city of cities' (Fenercom, 2016). The urban growth and transformation has blurred the boundaries between city and countryside, and so the distinction between overhead power lines in the periphery, and the underground power lines reserved for the city center, is not as easily made (Sumper et al., 2010).

Figure 5 shows how the high voltage lines, when entering Madrid, gird the urban fabric in a $20 \mathrm{~km}$-radius circular manner (overhead mainly around the south and west, and underground around the east and northeast side). Substations seem to accumulate in the south and east of the city center, and proliferate especially towards the southwest periphery, in line with the notable growth of artificial land in that direction. This southwest area is also subject to the impact of many overhead $220 \mathrm{kV}$ lines connecting the substations with the high voltage bypass. There is another noticeable accumulation of high voltage lines in the northeast access to the city, east of El Pardo Mount. However, this area seems to benefit from less overhead lines than the south.

A dynamic in recent years at a regional scale, and in close relation to the increase of artificial land and communication network, is the proximity of the urbanized land to sites of high ecological and scenic value, making the Natura 2000 areas especially vulnerable (Gallardo, Martínez-Vega, 2016). The proximity (or overlapping) of the electricity transportation system with the network of ecologically protected areas surrounding the metropolis is worth reflecting upon. Transmission lines are generally perceived as negative landscape elements (Soini, 2011), and while it may be argued that overhead lines produce a visual impact that could be avoided by carrying the cables underground, in terms of environmental impact, these might end up being more damaging (at least during the phase of execution of the works).

\section{Conclusion}

The southern boundary of Madrid became the main laboratory where the city's industrial transformation originated, giving way to the metropolis we know today. The building typology and siting of energy, industry and railway infrastructures determined its urban morphology since the mid-nineteenth century. It became a fringe in need of regeneration, especially from the 1970s onwards, after gradually losing its industrial character and transforming into a more consolidated residential mesh. This complex area, with numerous voids and scars, still today holds spaces of opportunity addressed in strategic land-use plans.

The memory of these transformations, detecting the driving forces of urban change, as well as their pace and magnitude, feeds into the idea that a dynamic view of historical landscape can be operational in adapting to paradigm shifts.

The urban growth and transformation has blurred the boundaries between city and countryside, and this effect is noticeable in today's complex system to bring the electricity power lines into the city. Their impact surpasses the mere visual facet, inviting to reflect on their compatibility with environmentally protected areas and new landscape values. 


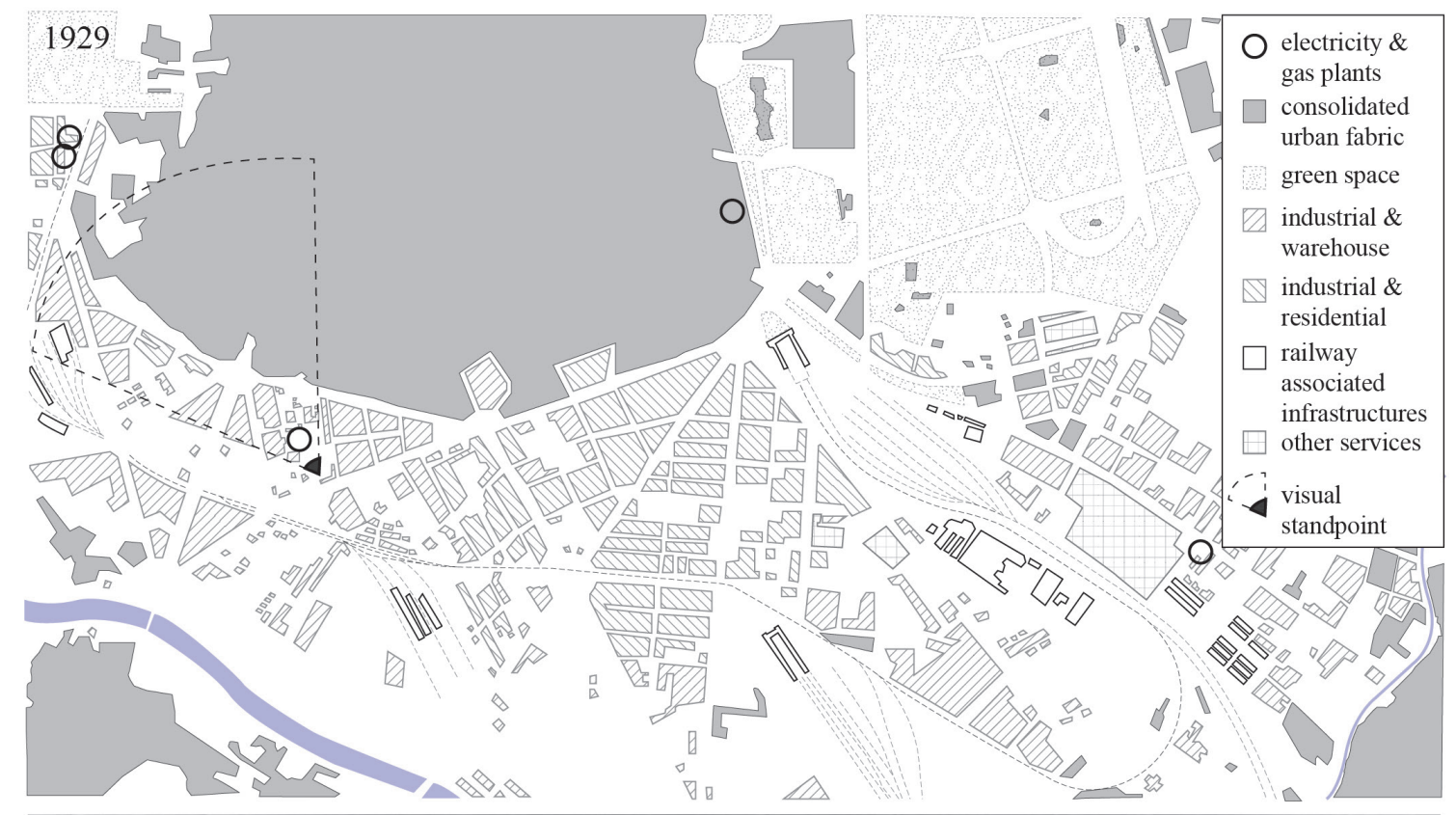

Ca. 1940

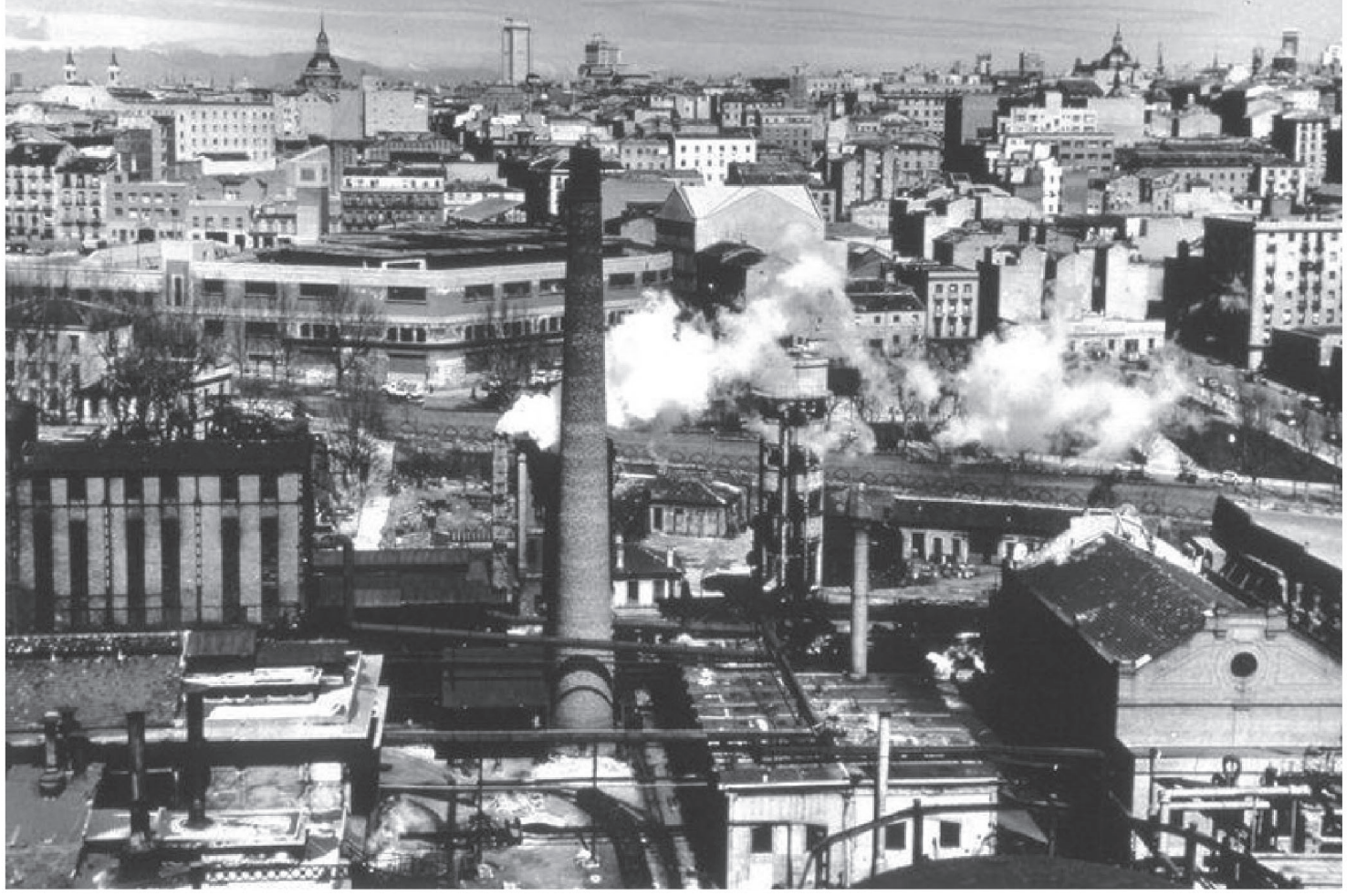

Figure 1. Industrial fabric in the south of Madrid in 1929) 

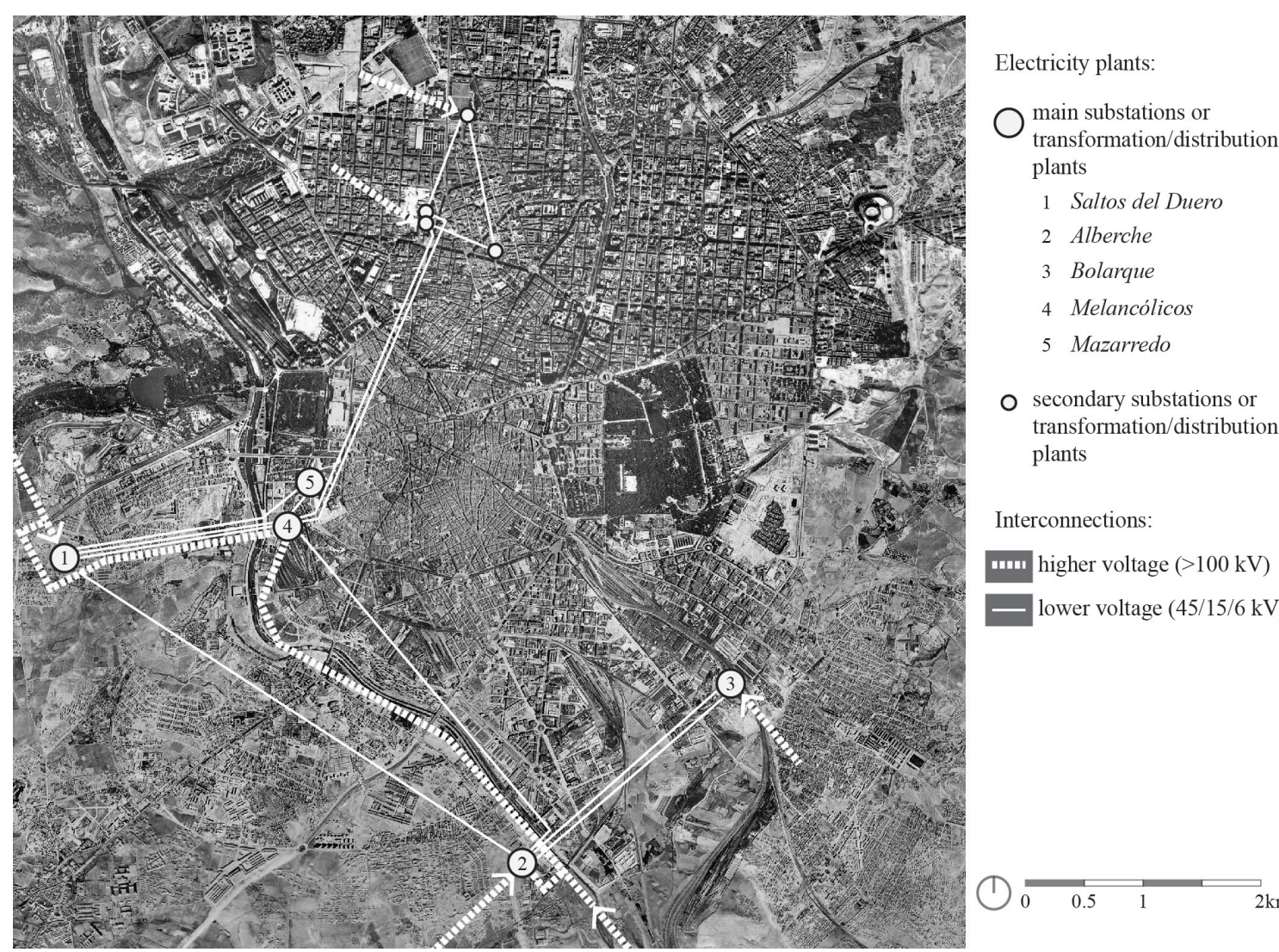

main substations or transformation/distribution plants

1 Saltos del Duero

2 Alberche

3 Bolarque

4 Melancólicos

5 Mazarredo

O secondary substations or transformation/distribution plants

\section{Interconnections:}

In" higher voltage (>100 kV)

- lower voltage $(45 / 15 / 6 \mathrm{kV})$

Figure 2. Electrical substations and connections in the city of Madrid in 1945
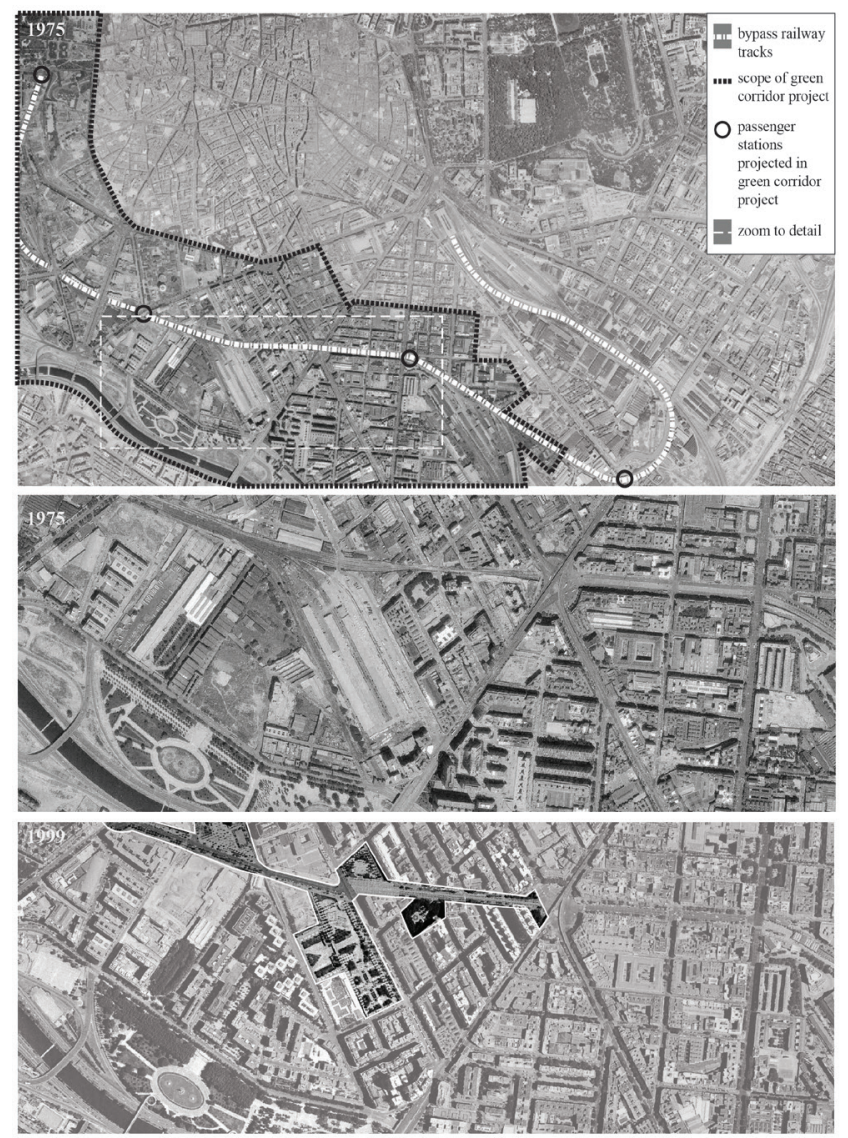

Figure 3. Urban regeneration plan for the south and west interior border of Madrid in the late twentieth century: Pasillo Verde 


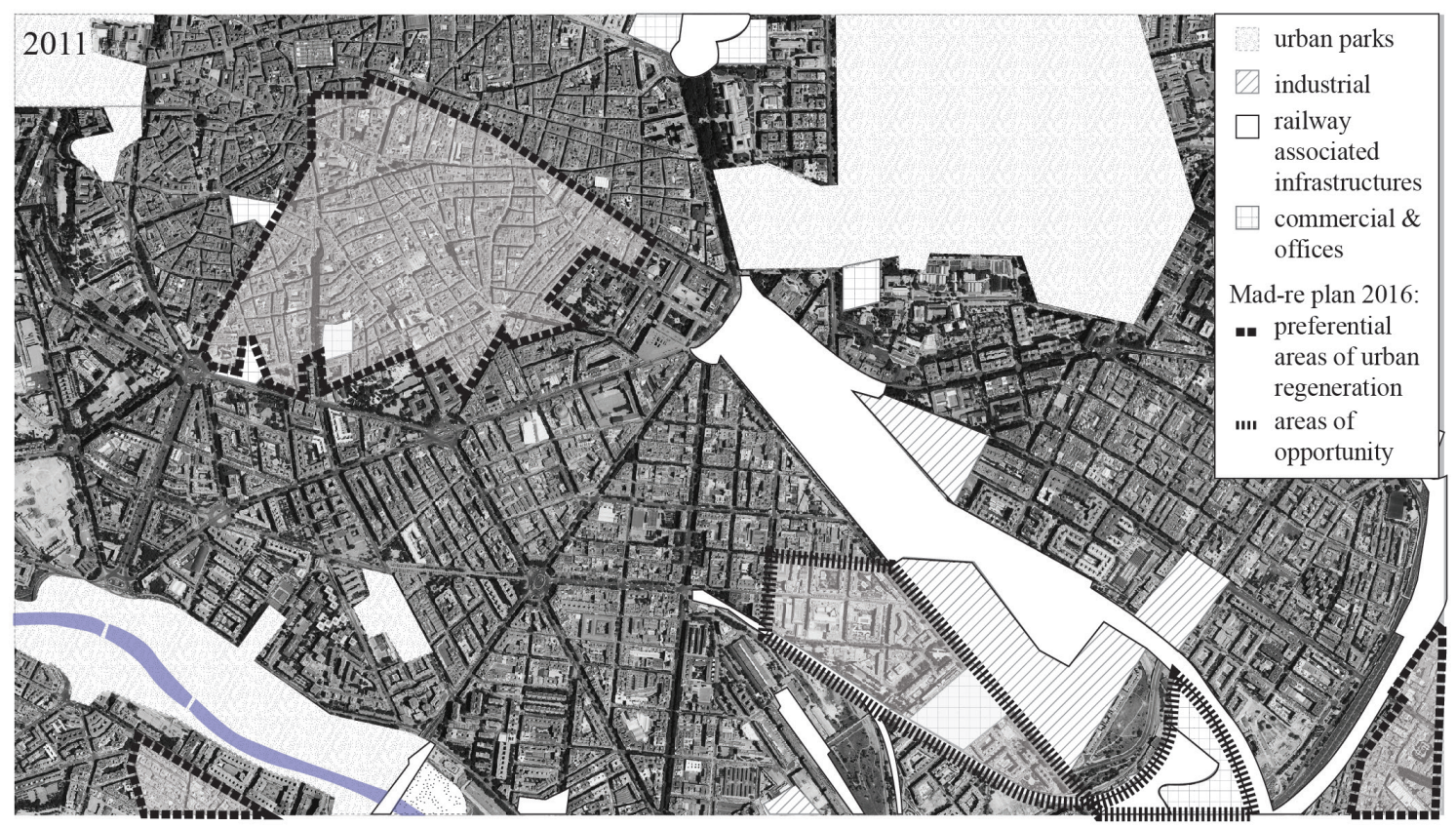

Figure 4. Land use, urban regeneration and spaces of opportunity in the south of Madrid

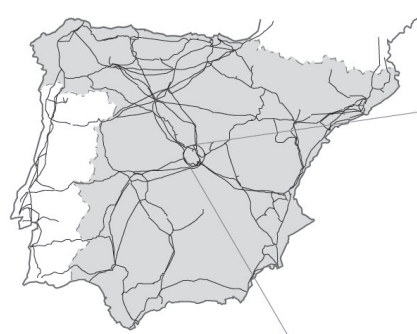

Power lines:

overhead underground

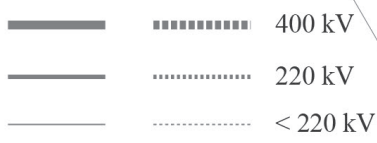

- electricity substations

$\square$ urban fabric

- Natura 2000 protected areas

rural/natural, non protected areas

— river course

main roads

-.- municipality boundary
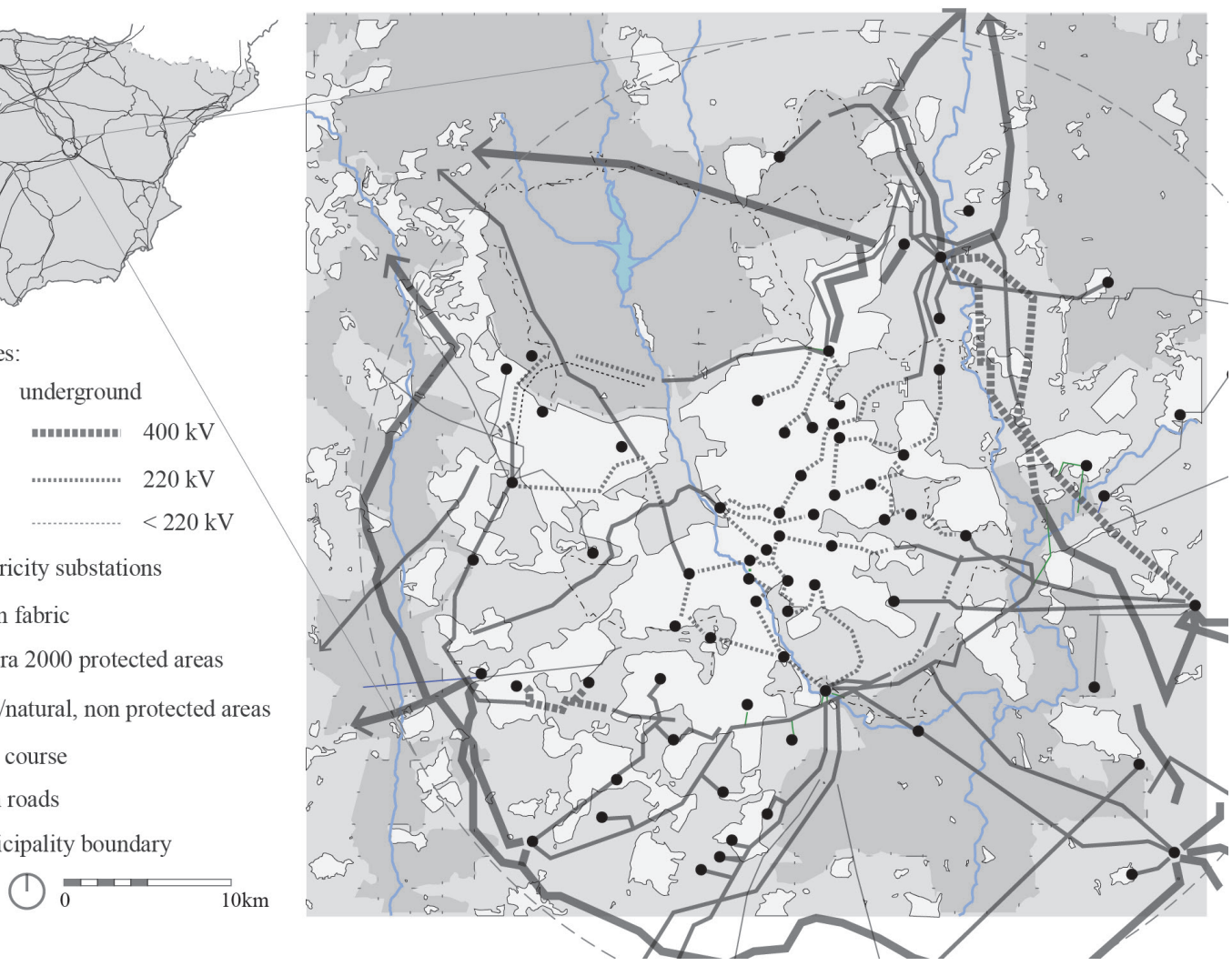

Figure 5. Electrical substations and main lines in the metropolis of Madrid 


\section{Acknowledgements}

This research has been developed in the framework of the State Plan Project of the Ministry of Economy and Competitiveness (HAR2014-57843-R), entitled "Proximity Landscapes of the City of Madrid. From the 19th Century to the present". We thank the General Secretariat of Science, Technology and Innovation for the funding of this project.

Likewise, we thank the Spanish Ministry of Education for the pre-doctoral scholarship (FPU14/05524) granted to co-author Carlota Sáenz de Tejada Granados in its FPU Program.

Lastly, we thank San Pablo-CEU University Foundation for the pre-doctoral scholarship granted to co-author Rocío Santo-Tomás Muro in its FPI Program.

\section{References}

Antrop, M. (2005) 'Why landscapes of the past are important for the future', Landscape and Urban Planning 70(1-2), 21-34.

Council of Europe (2000) European Landscape Convention (COE, Florence).

Fenercom and Autonomous Community of Madrid (2016) Stategic Plan of the Community of Madrid. Horizon 2020 (http:// www.fenercom.com/pages/publicaciones/ publicacion.php?id=235) accessed 24 May 2017.

Gallardo, M. and Martínez-Vega, J. (2016) 'Three decades of land-use changes in the region of Madrid and how they relate to territorial planning', European Planning Studies 24(5), 1016-1033.

Ivancic, A. (2010) Land\&Scape Series: Energyscapes (Gustavo Gili, Barcelona).

Olivares, S. (2016) 'Antonio Palacios Ramilo (1874-1945): la arquitectura del Metropolitano y su idea de metrópoli', unpublished $\mathrm{PhD}$ thesis, Universidad Politécnica de Madrid, Spain.

Palang, H., Spek, T., and Stenseke, M. (2011) 'Digging in the past: New conceptual models in landscape history and their relevance in peri-urban landscapes', Landscape and Urban Planning 100(4), 344-346.
Pinto, V. (coord.) (1995-2001) Madrid. Atlas Histórico de la Ciudad, Vol.1-Vol.2 (Lunwerg Editors and Fundación Caja Madrid, Madrid).

Rodríguez, E. J. (2003) 'El Madrid del origen del Canal de Isabel II', in Armada Díez de Rivera, J., Fuentes, M. \& Oliveros Eva, C. (eds.) Guía de los jardines de las Oficinas Centrales. Canal de Isabel II (Canal de Isabel II \& Real jardín Botánico CSIC, Madrid) 7-32.

Rodríguez, E. J. and Sáenz de Tejada, C. (2016) 'Evolution and Permanence of CityCountryside Views throughout the Urban Development of a City. Madrid as a Study Case', Procedia Engineering 161, 18791886.

Soini, K., Pouta, E., Salmiovirta, M., Uusitalo, M., and Kivinen, T. (2011) 'Local residents' perceptions of energy landscape: The case of transmission lines', Land use Policy 28(1), 294-305.

Spottorno, R. (1945) 'El suministro de energía eléctrica en Madrid', Revista De Obras Públicas, 93(2757), 48-54.

Sumper, A., Boix-Aragonès, O., VillafáfilaRobles, R., Bergas-Jané, J., and RamírezPisco, R. (2010) 'Methodology for the assessment of the impact of existing high voltage lines in urban areas', Energy Policy 38(10), 6036-6044.

Terán, F. (2006) En torno a Madrid. Génesis espacial de una región urbana (Autonomous Community of Madrid, Madrid).

Van der Horst, D. and Lozada-Ellison, L. M. (2010) 'Conflictos entre las energías renovables y el paisaje: siete mitos y la propuesta de manejo adaptativo y colaborativo', Nimbus 25, 231-251.

Vicente, V. (2015) El Ensanche Sur. Arganzuela (1860-1931). Los barrios negros (Los libros de la Catarata, Madrid). 